\title{
Components of the Essential Oil from Matteuccia struthiopteris
}

\author{
Mitsuo Miyazawa*, Eri Horiuchi and Jyunichi Kawata \\ Department of Applied Chemistry, Faculty of Science and Engineering, Kinki University (3-4-1, Kowakae, Higashiosaka-shi, Osaka 577- \\ 8502, JAPAN)
}

\begin{abstract}
A steam distilled oil obtained from Matteuccia struthiopteris was analyzed by GC and GC/MS. The oil was found to contain 103 volatile components, and $(E)$-phytol $(\mathbf{2 4 . 8 \%})$, nonanal $(\mathbf{1 5 . 1 \% )}$ and decanal $(\mathbf{7 . 6 \%})$ as the main compounds. The oil included two aldehydes known as sea-weed like odor, (8Z, $11 Z, 14 Z)$-heptadecatrienal $(0.6 \%)$ and $(8 Z, 11 Z)$-heptadecadienal $(0.1 \%)$. The most characteristic aroma compound was (6Z)-nonenal.
\end{abstract}

Key words: Matteuccia struthiopteris, Dryopteridaceae, essential oil, (E)-phytol, (8Z,11Z, 14Z)-heptadecatrienal, (8Z, 11Z)-heptadecadienal, (6Z)-nonenal

\section{INTRODUCTION}

Matteuccia struthiopteris ('Kusasotetsu' in Japanese) is a fern of the Dryopteridaceae and an edible wild plant that grows in colonies at damp area. It has been called 'Kogomi' and eaten as fry or tempura principally in the northeast part of Japan. Also the young buds can pick in April-June are eaten as boiling seasoned with soy sauce. Lately it comes to be cultivated for mass production.

It is known to have strong faculty for eliminating active oxygen and as the radical scavenger, chlorogenic acid ${ }^{1)}$ and L-O-caffeoylhomoserine ${ }^{2)}$ from $M$. struthiopteris were reported. Moreover legumin- and vicilin-like proteins have been isolated from spores of the fern ${ }^{3}$. Also dolichols have been isolated from leaves of the fern ${ }^{4)}$. Thus it comes to be a remarkable plant recently.

However, no studies on the essential oil from $M$. struthiopteris have been reported. The aim of this paper is therefore to identify the essential oil content and detect the important odor-active compounds from $M$. struthiopteris.

\section{EXPERIMENTAL}

\subsection{Material plant}

Samples of $M$. struthiopteris were harvested from Fukushima prefecture in Japan in April 2006.

\subsection{Isolation of the essential oil}

The above ground parts of $M$. struthiopteris (500 g) was hydrodistilled using a Likens-Nickerson-type apparatus with diethyl ether as the solvent to yield $0.002 \%$ of oil, which was dried over anhydrous sodium sulphate prior to analyses.

\subsection{Gas chromatography (GC)}

GC was carried out using a Hewlett Packard 6890 chromatograph equipped with a flame ionization detector (FID) on a capillary column (DB-WAX $15 \mathrm{~m} \times 0.25 \mathrm{~mm}$, film thickness $0.25 \mu \mathrm{m})$. The column temperature was programmed from $40^{\circ}-260^{\circ} \mathrm{C}$ at a rate of $4{ }^{\circ} \mathrm{C} / \mathrm{min}$ and held at $260^{\circ} \mathrm{C}$ for $5 \mathrm{~min}$. The injector and detector temperatures were $270^{\circ} \mathrm{C}$ and $280^{\circ} \mathrm{C}$, respectively. The flow rate of the carrier gas $(\mathrm{He})$ was $1.4 \mathrm{~mL} / \mathrm{min}$. Split ratio was 1:10.

\subsection{Gas chromatography/mass spectrometry (GC/MS)}

GC/MS was carried out with a Hewlett-Packard 6890/ Hewlett-Packard 5973 instrument. GC conditions were equipped on two capillary columns (DB-WAX $15 \mathrm{~m} \times 0.25$ $\mathrm{mm}$, film thickness $0.25 \mu \mathrm{m}$; HP-5MS $30 \mathrm{~m} \times 0.25 \mathrm{~mm}$, film thickness $0.25 \mu \mathrm{m})$. On DB-WAX, the GC oven temperature was kept at $40^{\circ} \mathrm{C}$ for $5 \mathrm{~min}$ and programmed to $260^{\circ} \mathrm{C}$ at a rate of $4^{\circ} \mathrm{C} / \mathrm{min}$ and then kept constant at $260^{\circ} \mathrm{C}$ for $5 \mathrm{~min}$. On HP-5MS, the column temperature was programmed from $40^{\circ}-260^{\circ} \mathrm{C}$ at a rate of $4^{\circ} \mathrm{C} / \mathrm{min}$ and held at $260^{\circ} \mathrm{C}$ for 5

*Correspondence to: Mitsuo Miyazawa, Depertment of Applied Chemistry, Faculty of Science and Engineering, Kinki University, 3-4-1, Kowakae, Higashiosaka-shi, Osaka 577-8502, JAPAN.

E-mail: miyazawa@apch.kindai.ac.jp

Accepted May 31, 2007 (received for review December 8, 2006)

Journal of Oleo Science ISSN 1345-8957 print / ISSN 1347-3352 online

http://jos.jstage.jst.go.jp/en/ 
min. The injector and detector temperatures were $270^{\circ} \mathrm{C}$ and $280^{\circ} \mathrm{C}$, respectively. The flow rate of the carrier gas (He) was $1.4 \mathrm{~mL} / \mathrm{min}$. The detector interface temperature was set at $280^{\circ} \mathrm{C}$ with the actual temperature in the MS source reaching approximately $230^{\circ} \mathrm{C}$ and the ionization voltage $70 \mathrm{eV}$. Split ratio was 1:10. Acquisition mass range was 39-450 amu.

\subsection{Gas chromatography/mass spectrometry-olfactometry (GC/MS-O)}

GC/MS-O was carried out using a Hewlett Packard 6890/Hewlett Packard 5973-Olfactory Detection Port 2. GC condition was equipped on a capillary column (HP-5MS $30 \mathrm{~m} \times 0.25 \mathrm{~mm}$, film thickness $0.25 \mu \mathrm{m}$ ). The column temperature was programmed from $40^{\circ}-260^{\circ} \mathrm{C}$ at a rate of $44^{\circ} \mathrm{C} / \mathrm{min}$ and held at $260^{\circ} \mathrm{C}$ for $5 \mathrm{~min}$. The injector and detector temperatures were $270^{\circ} \mathrm{C}$ and $280^{\circ} \mathrm{C}$, respectively. The flow rate of the carrier gas (He) was $1.4 \mathrm{~mL} / \mathrm{min}$. The detector interface temperature was set at $280^{\circ} \mathrm{C}$ with the actual temperature in the MS source reaching approximately $230^{\circ} \mathrm{C}$ and the ionization voltage $70 \mathrm{eV}$. Split ratio was 1:10. Acquisition mass range was 39-450 amu. The Chemstation software acquired two channel signals simultaneously, one channel for MS, and other channel from the olfactometer signal board. A signal sniffer, the author, recorded the aroma character manually.

\subsection{Aroma extract dilution analysis (AEDA)}

The flavor dilution (FD)-factor of the odorants in the essential oil was determined by aroma extract dilution analysis (AEDA) of the following dilution series ${ }^{5}$. The highest dilution was defined as FD-factor $1(6.9 \mathrm{mg} / \mathrm{ml})$. The oil was stepwise diluted $(1+1, \mathrm{v} / \mathrm{v})$ by addition of diethyl ether. Aliquots were then analyzed by GC/MS-O on the capillary column HP-5MS. The highest dilution at which an individual component could be detected was defined as the FD-factor for that odorant.

\subsection{Identification of constituents}

The components of the oil were identified by direct comparison with authentic samples on the basis of retention time and GC/MS, confirmed by analyses of authentic samples from the published in the literature ${ }^{6)}$ and our previous papers $^{7-12)}$.

\section{RESULT AND DISCUSSION}

The yield of oil obtained by steam distillation from $M$. struthiopteris was $0.002 \%(\mathrm{w} / \mathrm{w})$. Total ion chromatogram (TIC) of this oil showed the presence of 103 compounds (Fig. 1). As far as could be ascertained, 76 compounds (93.8\% of the total oil) were identified for the first time in this study on the oil from $M$. struthiopteris (Table 1). The main components were (E)-phytol (24.8\%), nonanal (15.1\%) and decanal $(7.6 \%)$. The oil was determined to be rich in many chain aldehydes.

Two unsaturated long-chain aldehydes were detected in the oil and identified as $(8 Z, 11 Z)$-heptadecadienal $(0.1 \%)$ and $(8 Z, 11 Z, 14 Z$ )-heptadecatrienal (0.6\%) (Fig. 2). They are odor compounds of green alga, such as Ulva pertusa ${ }^{13)}$, Monostroma nitidum ${ }^{14)}$ and Enteromorpha prolifera ${ }^{15}$, and known as representative seaweed aroma. The aldehydes have been isolated from not only seaweed but terrestrial plants, such as tobacco leaves ${ }^{16)}$, wheat ${ }^{12)}$ and honeysuckle flowers ${ }^{17}$.

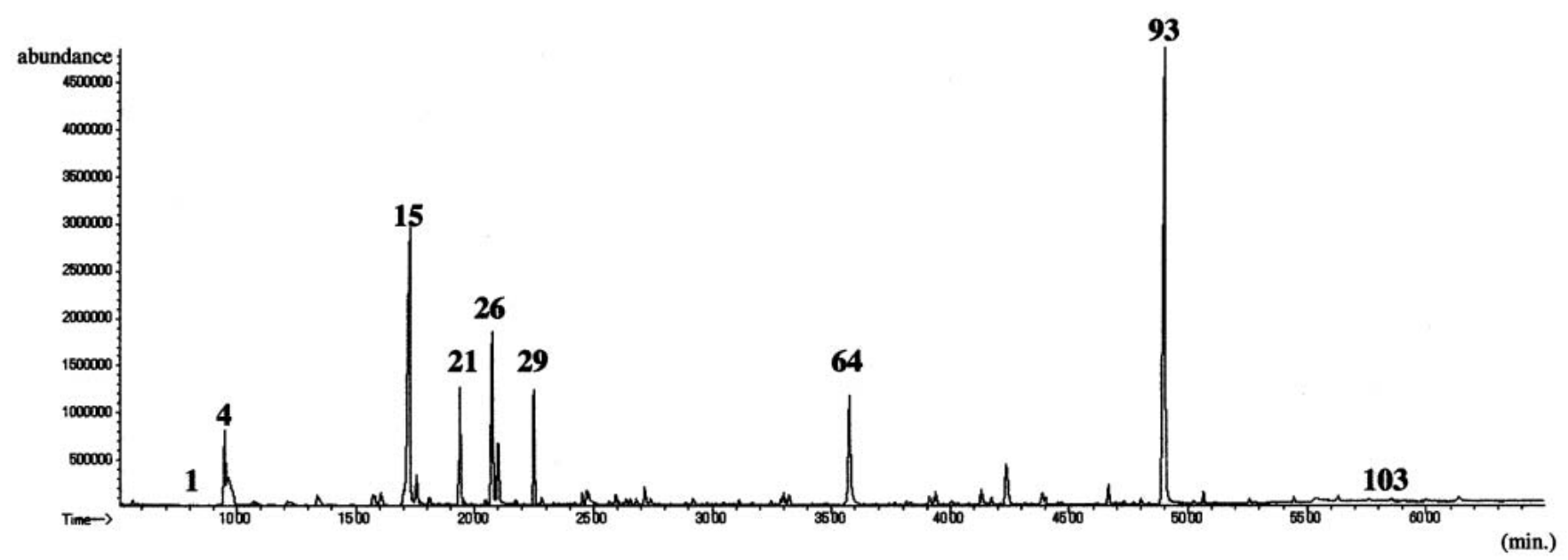

Fig. 1 The Total Ion Chromatogram of Essential Oil from Matteuccia struthiopteris. DB-WAX (15 $\mathrm{m} \times 0.25 \mathrm{~mm}$ i.d., film thickness $0.25 \mu \mathrm{m})$; flow rate of the carrier gas $(\mathrm{He}), 1.4 \mathrm{~mL} / \mathrm{min}$; oven temperature, $40^{\circ}-260^{\circ} \mathrm{C}$ at $4^{\circ} \mathrm{C} / \mathrm{min}$ and held at $260^{\circ} \mathrm{C}$ for $5 \mathrm{~min}$. 
Table 1 Compounds of the Essential Oil from Matteuccia struthiopteris.

\begin{tabular}{|c|c|c|c|c|c|c|c|c|c|}
\hline No & RI-W ${ }^{\text {a) }}$ & RI-5 ${ }^{\text {b) }}$ & Compound & Percentag & No & RI-W & RI-5 & Compound & Percentag \\
\hline 1 & 800 & 800 & octane & tr. & 50 & 1786 & & nerol & 0.3 \\
\hline 2 & 900 & 900 & nonane & $\operatorname{tr}$. & 51 & 1793 & & 2-tridecanone & 0.2 \\
\hline 3 & 1049 & & hexanal & 0.3 & 52 & 1799 & 1511 & tridecanal & 0.3 \\
\hline 4 & 1161 & 902 & heptanal & 12.6 & 55 & 1828 & & $\alpha$-ionone & 0.1 \\
\hline 5 & 1195 & & 1-pentanol & 0.9 & 56 & 1836 & & geraniol & 0.2 \\
\hline 6 & 1212 & 990 & 2-pentyl-furan & 0.2 & 58 & 1889 & & phenylethyl alcohol & 0.2 \\
\hline 7 & 1235 & 985 & 3-octanone & 0.5 & 59 & 1909 & 1613 & tetradecanal & 0.8 \\
\hline 10 & 1270 & 1001 & octanal & 1.7 & 60 & 1917 & 1489 & $\beta$-ionone & 0.6 \\
\hline 11 & 1282 & & 1-octen-3-one & 0.2 & 62 & 1953 & & caryophyllene oxide & tr. \\
\hline 12 & 1310 & & 2-methyl-3-octanone & 0.3 & 64 & 2011 & 1716 & pentadecanal & 6.1 \\
\hline 14 & 1345 & 866 & haxanol & 1.8 & 66 & 2058 & & 3-methyleicosane & $\operatorname{tr}$. \\
\hline 15 & 1380 & 1105 & nonanal & 32.6 & 69 & 2100 & 2100 & heneicosane & 0.2 \\
\hline 16 & 1389 & 993 & 3-octanol & 3.6 & 70 & 2111 & 1847 & $\begin{array}{l}\text { 6,10,14-trimethyl 2- } \\
\text { pentadecanone }\end{array}$ & 0.2 \\
\hline 17 & 1400 & 1400 & tetradecane & tr. & 71 & 2117 & 1817 & hexadecanal & 0.3 \\
\hline 18 & 1416 & 1096 & (6Z)-nonenal & tr. & 73 & 2161 & 1315 & 4-vinyl-o-guaiacol & 0.7 \\
\hline 21 & 1444 & 977 & 1-octen-3-ol & 10.0 & 74 & 2200 & 2200 & docosane & 0.3 \\
\hline 22 & 1450 & 968 & heptanol & tr. & 75 & 2201 & & methyl palmitate & 0.1 \\
\hline 23 & 1457 & & trans-linalool oxide & 0.3 & 76 & 2221 & 1919 & heptadecanal & 0.1 \\
\hline 24 & 1471 & & $\alpha$-copaene & $\operatorname{tr}$. & 78 & 2261 & & heptadecanol & 0.3 \\
\hline 25 & 1476 & 1382 & protoillud-6-ene & 0.6 & 79 & 2277 & & isophytol & tr. \\
\hline 26 & 1485 & 1207 & decanal & 16.3 & 80 & 2300 & 2300 & tricosane & 2.6 \\
\hline 27 & 1492 & 958 & benzaldehyde & 7.0 & 82 & 2358 & 1895 & (8Z,11Z,14Z)-heptadecatrienal & 0.6 \\
\hline 28 & 1515 & & $(2 E)$-nonenal & 0.8 & 83 & 2365 & & octadecanol & 0.3 \\
\hline 29 & 1540 & 1101 & linalool & 8.0 & 84 & 2400 & 2400 & tetracosane & tr. \\
\hline 30 & 1550 & 1068 & octanol & 0.9 & 85 & 2408 & 1295 & indole & 0.2 \\
\hline 31 & 1567 & 1433 & $\gamma$-elemene & 0.5 & 87 & 2500 & 2500 & pentacosane & 0.7 \\
\hline 33 & 1579 & & terpinen-4-ol & 0.2 & 90 & 2548 & 1889 & $(8 Z, 11 Z)$-heptadecadienal & 0.1 \\
\hline 34 & 1585 & & 2-undecanone & 0.2 & 91 & 2563 & & (Z)-phytol & 0.2 \\
\hline 36 & 1595 & & $\beta$-cyclocitral & 0.4 & 93 & 2610 & 2117 & (E)-phytol & 24.8 \\
\hline 37 & 1606 & & $(2 E)$-nonenol & 1.0 & 94 & 2662 & & phenanthrene & tr. \\
\hline 38 & 1612 & 1043 & phenylacetaldehyde & 3.3 & 95 & 2700 & 2700 & heptacosane & 0.4 \\
\hline 40 & 1652 & 1160 & nonanol & 1.4 & 97 & 2800 & & octacosane & 0.1 \\
\hline 41 & 1667 & 1164 & $4^{\prime}$-hydroxy-acetophenone & 0.9 & 99 & 2900 & & nonacosane & 0.2 \\
\hline 42 & 1672 & & (3Z)-nonenol & 0.7 & 100 & 2929 & & hexadecanoic acid & 0.7 \\
\hline 43 & 1681 & & $\alpha$-terpineol & 0.7 & 101 & 3000 & & triacontane & 0.2 \\
\hline 44 & 1693 & 1410 & dodecanal & 1.7 & 102 & 3058 & & squalene & 0.1 \\
\hline 45 & 1701 & 1184 & naphthalene & 1.0 & 103 & 3100 & & hentriacontane & 0.1 \\
\hline 46 & 1714 & & $\begin{array}{l}\text { 1,2-dihydro-1,1,6-trimethyl- } \\
\text { naphthalene }\end{array}$ & 0.2 & & & & & \\
\hline 47 & 1753 & & decanol & 0.4 & & & & total & 93.8 \\
\hline
\end{tabular}

${ }^{\text {a) }}$ RI-W: Retention index on a DB-WAX column; ${ }^{\text {b) }}$ RI-5: Retention index on a HP-5MS column; Percentage was rdetected to total detected compounds by GC; $\operatorname{tr}$ : trace $<0.1 \%$. 
Table 2 Odor-active Compounds in the Essential Oil from Matteuccia struthiopteris.

\begin{tabular}{cccc}
\hline${ }^{\text {a) }}$ RI-5 & FD-factor & Aroma quality & Aroma compound \\
\hline 873 & 16 & green odor & hexanol \\
897 & 8 & bitter odor & heptanal \\
919 & 1 & fatty odor & unknown \\
973 & 4 & sweet, mushroom-like odor & 1-octen-3-ol \\
997 & 2 & refreshing odor & octanal \\
1040 & 16 & green, earthy odor & phenylacetaldehyde \\
1076 & 16 & plastic-like odor & unknown \\
1090 & 64 & green, refreshing odor & (6Z)-nonenal \\
1096 & 8 & fresh, floral odor & linalool \\
1176 & 32 & earthy odor & unknown \\
1192 & 2 & green, refreshing odor & nonanal \\
1382 & 2 & vegetable-like odor & unknown \\
1304 & 1 & green, vegetable-like odor & unknown \\
\hline
\end{tabular}

a) RI-5: Retention index on a HP-5MS column.

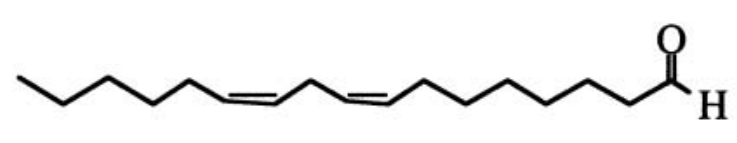

(8Z,11Z)-heptadecadienal

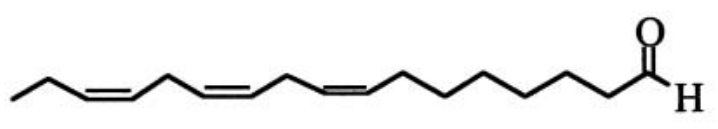

(8Z,11Z,14Z)-heptadecatrienal

Fig. 2 Structure of Two Unsaturated Long-chain Compounds from Matteuccia struthiopteris.

Thereupon the important odor-active compounds in essential oil from $M$. struthiopteris were analyzed by GC/MS-O and AEDA to estimate that the characteristic aldehydes were concerned with odor of $M$. struthiopteris. The results of GC/MS-O and AEDA studies were given in Table 2. Two unique aldehydes couldn't be smelt because of the low concentration. (6Z)-Nonenal savors green like odor played an important role in the characteristic aroma of $M$. struthiopteris (FD-factor $>64$ ). Besides green like odor, linalool as sweet odor concerned with aroma of the oil.

\section{ACKNOWLEDGMENT}

This work was supported by Grant-in-Aid from the Japan Socitey for the Promotion of Science (No. 19300244), and a grant from Ministry of Education, Culture, Sports, Science and Technology for the "High-Tech Research Center" project for Private Universities, 2004-2008.

\section{References}

1. Syrchina, A.I.; Pechurina, N.N.; Vereshchagin, A.L.; Gorshkov, A.G.; Tsapalova, I.E.; Seininov, A.A. Chemical study of Matteuccia struthiopteris. Knim. Prir. Soedin. 608-609 (1993).

2. Kimura, T.; Suzuki, M.; Takenaka, M.; Yamagishi, K.; Shinmoto, H. L-O-Caffeoylhomoserine from Matteuccia struthiopteris. Phytochemistry 65, 423-426 (2004).

3. Kakhovskaja, I.; Rudacova, A.; Manteuffel, R. Leguminand vicilin-like proteins from spores of the fern Matteuccia struthiopteris. J. Plant Physiol. 160, 583-588 (2003).

4. Wojtas, M.; Bienkowski, T.; Zelman-Femiak, M.; Tateyama, S.; Sagami, H.; Chojnacki, T.; Danikiewicz, W.; Swiezewska, E. Dolichols of the fern Matteucia struthiopteris. Acta Biochim. Pol. 52, 255-259 (2005).

5. Schieberle, P.; Grosch, W. Changes in the concentrations of potent crust odourants during storage of white bread. Flav. Fragr. J. 7, 213-218 (1992).

6. Adams, R.P. Identification of essential oil components by gas chromatography/quadrupole mass spectroscopy. Allured Publ. Corp., Carol Stream, IL, (2001).

7. Miyazawa, M.; Fujita, T.; Yamafuji, C.; Matsui, M.; Kasahara, N.; Takagi, Y.; Ishikawa, Y. Chemical composition of volatile oil from the roots of Periploca sepium. J. Oleo Sci. 53, 511-513 (2004).

8. Miyazawa, M.; Kawata, J. Identification of the key aroma compounds in dried roots of Rubia cordifolia. 
J. Oleo Sci. 55, 37-39 (2006).

9. Utsunomiya, H.; Kawata, J.; Chanoki, W.; Shirakawa, N.; Miyazawa, M. Components of essential oil from woods of Prunus mume Sieb. et Zucc. J. Oleo Sci. 54, 609-612 (2005).

10. Miyazawa, M.; Okuno, Y. Volatile components from the roots of Scrophularia ningpoensis Hemsl. Flav. Fragr. J. 18, 398-400 (2003).

11. Miyazawa, M.; Kawata, J. Composition of the essential oil of rootstock from Cimicifuga simplex. Nat. Prod. Res. 20, 542-547 (2006).

12. Hamilton-Kemp, T.R.; Andersen, R.A. Volatiles from winter wheat: identification of additional compounds and effects of tissue source. Phytochemistry 25, 241243 (1986).

13. Fujimura, T.; Kawai, T.; Shiga, M.; Kajiwara, T.; Hatanaka, A. Long-chain aldehyde production in thalli culture of the marine green alga Ulva pertusa. Phytochemistry 29, 745-747 (1990).

14. Kajiwara, T.; Hatanaka, A.; Kawai, T.; Ishihara, M.; Tuneya, T. Long chain aldehydes in the green marine algae Ulvaceae. Nippon Suisan Gakkaishi 53, 1901 (1987).

15. Obata, Y.; Igarashi, H.; Matano, K. Aroma of sea algae. 1. Aromatic components of green algae. Riechstoffe, Aromen, Koerperpflegemittel 21, 284, 287-288 (1971).

16. Kawasaki, W.; Matsui, K.; Akakabe, Y.; Itai, N.; Kajiwara, T. Long-chain aldehyde-forming activity in tobacco leaves. Phytochemistry 49, 1565-1568 (1998).

17. Ikeda, N.; Ishihara, M.; Tsuneya, T.; Kawakita, M.; Yoshihara, M.; Suzuki, Y.; Komaki, R.; Inui, M. Volatile components of honeysuckle (Lonicera japonica Thunb.) flowers. Flav. Fragr. J. 9, 325-331 (1994). 